\title{
Anti-Proliferative Effects of Methanol and Water Extracts of Pyrrosia piloselloides on the Hela Human Cervical Carcinoma Cell Line
}

\author{
Mohd Dasuki Sul 'ain', Fashihah Zakaria', Muhammad Farid Johan²
}

\begin{abstract}
Background: Cervical cancer is one of the most commonly diagnosed neoplasms and a leading cause of cancer death among females worldwide. Limitations with conventional medical treatments have driven researchers to search for alternative approaches using natural products. This study aimed to detemine potential anti-proliferative effects of methanol and water extracts of Pyrrosia piloselloides (P. piloselloides) on the HeLa cell line. Methods: 3-(4,5-Dimethylthiazol-2-yl)-2,5-diphenyltetrazolium bromide (MTT) assays were performed to determine IC50 concentrations and apoptosis analysis was by flow cytometry. To identify chemical compounds in the extracts, gas chromatography-mass spectrometry (GC-MS) was employed. Results: P. piloselloides methanol extracts (PPME) showed antiproliferative effects on $\mathrm{HeL}$ awith an IC50 of $16.25 \mu \mathrm{g} / \mathrm{mL}$ while the P. piloselloides water extract (PPWE) was without influence. Neither extract showed any significant effects on apoptosis. GC-MS analysis, revealed 5-hydroxymethylfurfural (23.1\%), allopurinol (8.66\%) and 3, 5-dihydroxy-6-methyl-2,3-dihydropyran-4-one (7.41\%) as major components in the PPME, while sulfolan-3-ol (10.1\%), linoleic acid (9.06\%) and $\beta$-sitosterol acetate $(7.98 \%)$ predominated in the PPWE case. Conclusion: This first study of P. piloselloides showed PPME to exert potent anti-proliferative effect on HeLa cell lines. Further research now needs to be performed to establish the mechanisms of inhibition.
\end{abstract}

Keywords: Pyrrosia piloselloides- antiproliferative- HeLa cells

Asian Pac J Cancer Prev, 20 (1), 185-192

\section{Introduction}

Cancer is a generic term for a large group of diseases characterized by the growth of abnormal cells beyond their usual boundaries which invade adjoining parts of the body and/or spread to the other organs. Most of this abnormal growth are irreversible and cause numerous alterations that can distract the body systems. Cancer also can be described as malignant tumor or neoplasm, while the process of normal cell turning into cancer cells is called carcinogenesis. The disease can affect almost any part of the body and has many anatomies and molecular subtypes that each required specific management strategies to avoid or inhibit it. According to 2014 World Health Organisation (WHO) report, cancer is the second leading cause of death globally accounted for 8.8 million deaths in the year. There are more than 200 different types of cancer detected but the world most common cancer affected among men are lung, prostate, colorectal, stomach and liver cancers (Torre et al., 2015). While breast, cervix, colorectal, lung and stomach cancers are the most common diagnosed among women (Torre et al., 2015). Although some of the cancers are been said preventable yet it seems still becoming as one of the leading causes of death to human for example the $\mathrm{CxCa}$.

$\mathrm{CxCa}$ is a cancer that occurs at a part of female reproductive system called cervix; the entrance to uterus from vagina. Most $\mathrm{CxCa}$ cases are caused by an infection of a virus called Human Papilloma virus (HPV) on the surface of the cervix which led to cervical dysplasia or abnormal growth of the cervical cells (Bruni et al., 2016). Based on the statistics of World Health Organization (WHO), approximately 270,000 women died from $\mathrm{CxCa}$ in 2016 where more than $85 \%$ of the deaths occur in low and middle-income countries (Bruni et al., 2016). Hence, the highest incidence rates can been found in such countries such as in Central America, East Africa, Southeast Asia and Western Pacific (International Agency for Research on Cancer; GLOBOCAN 2012 v1.0 2013). Today, this illness has become one the gravest threat to women's lives worldwide. Though the number of $\mathrm{CxCa}$ cases illustrate a decrease in most of developed regions over the past three decades, but it keeps increasing or remaining unchanged in almost all developing countries including in the Asia Pacific's (International Agency for Research on Cancer; GLOBOCAN 2012 v1.0 2013). Likewise, the disease has also turn to be one of the most 
common cancers and death causal among Malaysian females (Health Ministry of Malaysia, 2009). According to Malaysian National Cancer Registry Report in 2016, the risk of Malaysian women to get $\mathrm{CxCa}$ is one over 116 where almost $60 \%$ of cases were detected at mild and moderate stage. Most of the patients are from the beginning of reproductive age group, 25-45 years old, and those who reached the menopause stage (International Agency for Research on Cancer; GLOBOCAN 2012 v1.0, 2013; Malaysian National Cancer Registry Report, 2016). Current estimates indicate that 2,145 women are diagnosed with $\mathrm{CxCa}$ and 621 dies from the disease annually.

While local governing agencies are pushing the Papanicolaou smear (Pap smear) and HPV vaccine as the attempts to curb future $\mathrm{CxCa}$ rates, the effort of looking for cancer preventive and therapeutic drugs originating from the natural sources such as plants have grown in popularity of researchers. The scientific investigations on various herbs consisting bioactive compounds as natural chemopreventive and chemotherapeutics proved a promising future in combating $\mathrm{CxCa}$. Some of the advantages that derived from this alternative therapeutic method include lower side effects and toxicity, higher accessibility and availability and lower cost consumption. Recently, a number of studies have demonstrated in vitro and/or in vivo that some plants can be new and potential anticancer agents (Kwon et al., 2006; Li et al., 2007; Kwon et al., 2007; Kim et al., 2010). Therefore, many researchers believe that chances of discovering more effective drugs to forbid or treat the life-threatening diseases such as $\mathrm{CxCa}$ is still wide open since the tropical Southeast Asian rainforest like those dominates in Malaysia is very rich with various diversities of plants and herbs (Wan Ghazali et al., 2016; Alternative Medicine, 2002).

$P$. piloselloides is one of the most common epiphytic fern originated from family of Polypodiaceae which naturally grows small in size but abundant and knows as "pokok duit-duit (money plant)" in Malaysia. The $P$. piloselloides plant usually appears creeping on the trunks of old trees at the roadside or in small jungle that have balanced moist and warm conditions to expand. Literally, this fern can be extensively found in Tropical Asia regions. The rhizomes are only approximately $1 \mathrm{~mm}$ in diameter but extremely long and strong covered with small, almost round or heart-shaped scales, the leaves. It is reported that its leaves are used by aboriginal Negritos and Southern Thais as pain and fever relievers (Neamsuvan et al., 2014; Lin, 2005). In Indonesia, it is an old medicinal practice to use the leaves to treat breast cancer disease (Wulandari et al., 2013). Local folks also use it to soothe gallstone and as a skin rashes poultice. P. piloselloides leaves will either be crushed for external applications or decocted for oral consumptions (Lin, 2005). Previous study has reported that the plant contains flavonoids, tannins, steroid or triterpenoid, essential oils and glycosides which are highly potential to act as anticancer agent (Sahid et al., 2013). Thus, this present study aims to evaluate the antiproliferative attribution of $P$. piloselloides methanol and water extracts on cervical carcinoma cell line, HeLa as human in vitro model system. Following the treatments to the cell line, the concentration 50\% inhibition in the cells population (IC50) will be decided. The IC50 value will be used to examine the apoptosis induction of treatments using flow cytometer analysis. Later, the extracts will be analyzed by GC-MS to identify the probable bioactive compounds in the $P$. piloselloides.

\section{Materials and Methods}

\section{Sample collection and preparation}

Fresh P. piloselloides plants were collected from Pasir Hor, Kelantan, Malaysia. The authentication of the plant was made at Herbarium Kulliyyah of Pharmacy, International Islamic University Malaysia by the botanist. The identification of $P$. piloselloides specimen was deposited with a voucher number PIIUM 0305. To prepare $P$. piloselloides dry sample, the leaves were washed, oven-dried at $50^{\circ} \mathrm{C}$ for several days in incubator (Binder, Germany) and ground using a heavy duty grinder (Golden Bull, Malaysia). The powder then was kept and sealed in Duran bottles at room temperature until further used.

\section{Preparation of methanol and water extracts}

The $P$. piloselloides methanol extract (PPME) was prepared by soaking the $50 \mathrm{~g} P$. piloselloides powder in $500 \mathrm{ml}$ of absolute methanol with 1:10 (w/v) ratio and was shaken overnight at $1500 \mathrm{rpm}$ using shaker incubator (Protech, Malaysia) at room temperature. The mixture was filtered using $150 \mathrm{~mm}$ Whatman filter paper and concentrated using rotary evaporator (Heidolph, South Korea) followed by evaporating it in the fume hood for several days for complete solvent evaporation. The filtered methanol residue was dried out before further used in $P$. piloselloides water extraction. For $P$. piloselloides water extract (PPWE), all previous extraction steps were repeated using distilled water. The filtered extract was froze dried using freeze dryer (ILshin Lab, South Korea) till the PPWE would turn into powder form. Concentrated PPME and powdered PPWE were sealed separately in universal bottles and stored at $4^{\circ} \mathrm{C}$ for future usage.

\section{Cytotoxicity evaluation by MTT assay}

HeLa and L929 cells (American Type Culture Collection Company, USA) with $80-90 \%$ confluent were plated into 96 wells microliters plate $\left(5 \times 10^{4}\right.$ cells/ $\mathrm{mL})$. The cells were maintained at $37^{\circ} \mathrm{C}$ in a humidified incubator with an air mixture containing $5 \%(\mathrm{v} / \mathrm{v}) \mathrm{CO}_{2}$ for 24 hours. The adherent cells were trypsinised to detach the cells. The media then were replaced by $200 \mu \mathrm{L}$ of fresh complete media in each well. Cells were treated with $2 \mu \mathrm{L}$ of a serial dilution of PPME or PPWE from $0.39 \mu \mathrm{g} / \mathrm{mL}$ to $100.0 \mu \mathrm{g} / \mathrm{mL}$. Two microliter of dimethyl sulfoxide (DMSO) and Tamoxifen (Sigma Chemical Co., USA), in same dilutions were used as negative and positive controls respectively. The cells then were incubated for 72 hours. The cell viability was subjected using MTT assay kit based on the guidelines from manufacturer and Tian and Zang (2015) method with slight modifications. The optical densities (OD) were measured through spectrophotometric plate reader (Thermo Electron Co., USA) at $570 \mathrm{~nm}$. The viability percentage was calculated using below formula: 

x $100 \%$

\section{OD untreated cells}

Dose-response curves were constructed to obtain the IC50 values. A graph of cell viability determined from MTT Assay was expressed and compared. Extract with lowest IC50 on HeLa cells would be further preceded for apoptosis assessment.

\section{Apoptosis assessment by flow cytometer analysis}

T1x105 of HeLa cell line was seeded in six well-plates. After the incubation at $37^{\circ} \mathrm{C}$ in $5 \% \mathrm{CO}_{2}$ and a humidified atmosphere for 24 hours, PPME was added into the HeLa cells at the concentration of IC50 value. After 24, 48 and 72 hours treatments, the PPME-treated and untreated HeLa cells were collected and assessed using Vybrant TM Apoptosis Assay Kit 3 (Molecular Probes, USA). Briefly, the collected cells were centrifuged and the supernatants were discarded. Then, cells were washed and centrifuged twice with cold PBS before resuspending them with $1 \mathrm{x}$ binding buffer at $1 \times 10^{6}$ cells $/ \mathrm{mL}$. The cells were transferred to $5 \mathrm{~mL}$ FACs tubes (Becton-Dickinson, USA) with $5 \mu \mathrm{L}$ of FITC Annexin $\mathrm{V}$ and $1 \mu \mathrm{L}$ of Propidium Iodide (PI). The mixture was gently vortexed and incubated at dark room temperature for 15-30 minutes. Lastly, $400 \mu \mathrm{L}$ of $1 \mathrm{X}$ Binding Buffer was added to each tube within one hour prior to flow cytometry analysis. For staining controls, one tube of each unstained, FITC Annexin V and PI were prepared and analyzed. Detected cell populations were grouped and labeled into four quadrants; Q1 - dead or debris cells which only permeable to PI and excluded from analysis, Q2 - cells in late apoptosis or necrosis stage which would be stained by Annexin V and PI, Q3 - viable cells and unstained by Annexin V and PI and Q4 - cells at early apoptosis and positive Annexin V and PI staining. The total percentage of apoptosis were summed up from periods of early apoptotic, Q4 to late apoptotic, Q2.

\section{GC-MS Analysis}

The GC-MS analysis was carried out on a GC Agilent Technologies 6890 Network System and gas chromatography interfaced to a mass spectrometer Agilent Technologies 5973 inert Mass Selective Detector. Ten micrograms of PPME or PPWE dissolved in $2 \mathrm{~mL}$ methanol were transferred into GC-MS vial. This instrument employed the following condition: Column HP-MS ( 30 x $0.25 \mathrm{~mm}$ ID x 0.25 film thickness), operating in electron impact mode at $70 \mathrm{Ev}$, helium $(99.999 \%)$ was used as carrier gas at a constant flow of $1.2 \mathrm{~mL} / \mathrm{min}$, injection volume of $1 \mu \mathrm{L}$ was employed (splitless mode), injection temperature of $280^{\circ} \mathrm{C}$. The oven temperature was programmed from $70^{\circ} \mathrm{C}$ (isothermal for 2 minutes) with an increase of $20^{\circ} \mathrm{C} / \mathrm{min}$, to $280^{\circ} \mathrm{C}$ for $30 \mathrm{~min}$. The scan rate was $2.42 \mathrm{~s}$ per scan. The solvent delay was $2 \mathrm{~min}$ and the total running time was $42.5 \mathrm{~min}$. For the identification of the components, the interpretation on mass spectrum GC-MS was conducted using the database of National Institute Standard and Technologies (NIST) 2002. The spectrum of the unknown component was compared with the spectrum of the known components in the NIST library. The name of the compounds, retention time and percentage area were ascertained in the end.

\section{Statistical analysis}

All measurements were carried out in triplicates from three independent experiments and the results were expressed as the mean \pm SEM. The data were first tested for their normality using Kolmogorov-Smirnov test. The statistical significances of data obtained were calculated and regulated using two ways analysis of variance (ANOVA). For all the comparisons, the level of $\mathrm{p} \leq 0.05$ was considered significant. All statistical analysis was performed using Graph Pad PRISM Version 6.0 by GraphPad Software Inc, California.

\section{Results}

\section{Cell proliferation - MTT assay}

Based on the Table 1, the IC50 value of PPME on HeLa cell was $16.25 \pm 1.96 \mu \mathrm{g} / \mathrm{mL}$ while the extract seemed to have no growth inhibition on L929 cell when the graph exhibits linear trend in all concentrations (Figure 2). Meanwhile, PPWE experienced the same style when tested on HeLa cell but showed a slight emergence on cell viability when its concentration have been increased. Therefore, it can be described PPWE has no antiproliferative effect either on carcinoma $\mathrm{CxCa}$ or normal cell lines. As a result, based on the Figures 1 and 2, the IC50 values of PPME on L929 cell and PPWE on both treated cell lines were higher than $100 \mu \mathrm{g} / \mathrm{mL}$. On the hand, as the positive control drug, tamoxifen appeared to have greatest value of IC $50,1.87 \pm 1.32 \mu \mathrm{g} / \mathrm{mL}$, to the cancer cell line, HeLa. However, the IC50 value of tamoxifen in the L929 cell was more eminent than the IC50 value on the HeLa cell with $1.09 \pm 0.59 \mu \mathrm{g} / \mathrm{mL}$.

\section{Apoptosis assessment by flow cytometry analysis}

In order to detect apoptosis and effect of PPME in cell cycle progression of HeLa, flow cytometry analysis using PI and Annexin V was carried out. However, in comparison to the untreated HeLa cells, there were no significant difference was found in total apoptosis of PPME-treated HeLa cells after 24, 48 and 72 hours observation as shown in Figures 3 and 4.

\section{Gas Chromatography-Mass Spectrometry (GC-MS) Analysis}

The list of phytochemical compounds in PPME and PPWE resulting from GC-MS analysis are reported in Tables 2 and 3 respectively. Their qualitative and

Table 1. Cytotoxicity Activities of PPME, PPWE and Tamoxifen on HeLa and L929 Cell Lines

\begin{tabular}{lcc}
\hline & \multicolumn{2}{c}{ Cell growth inhibition, $\mathrm{IC}_{50}(\mu \mathrm{g} / \mathrm{mL})$} \\
& HeLa cell & L929 cell \\
\hline PPME & $16.25 \pm 1.96$ & $>100$ \\
PPWE & $>100$ & $>100$ \\
Tamoxifen & $1.87 \pm 1.32$ & $1.09 \pm 0.59$ \\
\hline $\mathrm{IC}_{50}$ values are presented as means \pm SEM; PPWE, P. piloselloides \\
methanol extract; PPWE, P. piloselloides water extract
\end{tabular}

Asian Pacific Journal of Cancer Prevention, Vol 20 


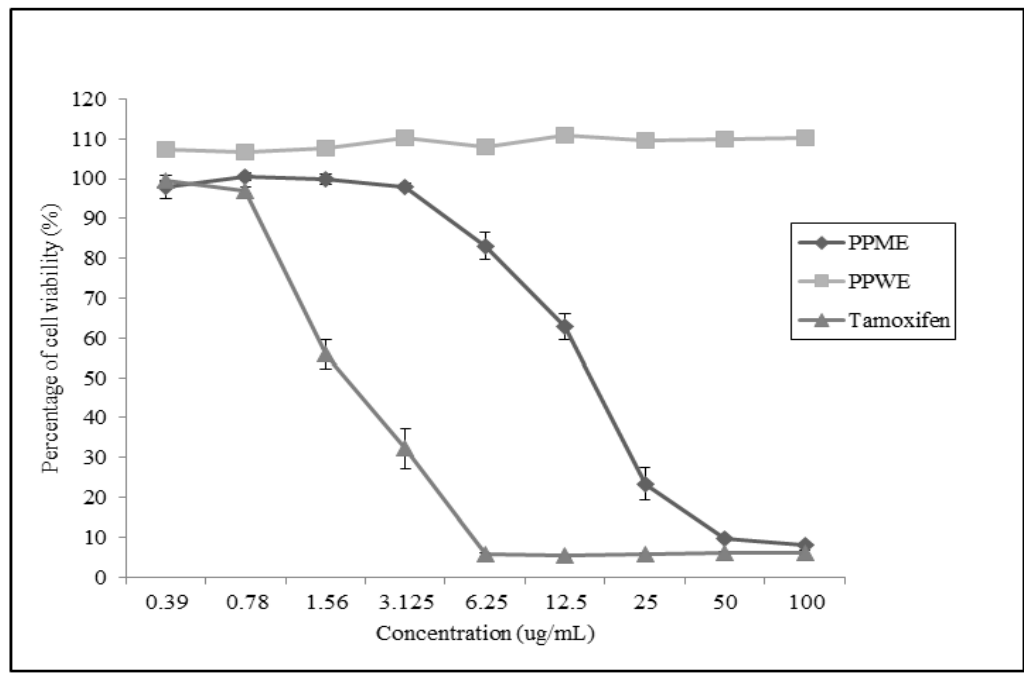

Figure 1. The Percentage of Cells Viability of HeLa Cell at Different Concentrations of PPME, PPWE and Tamoxifen

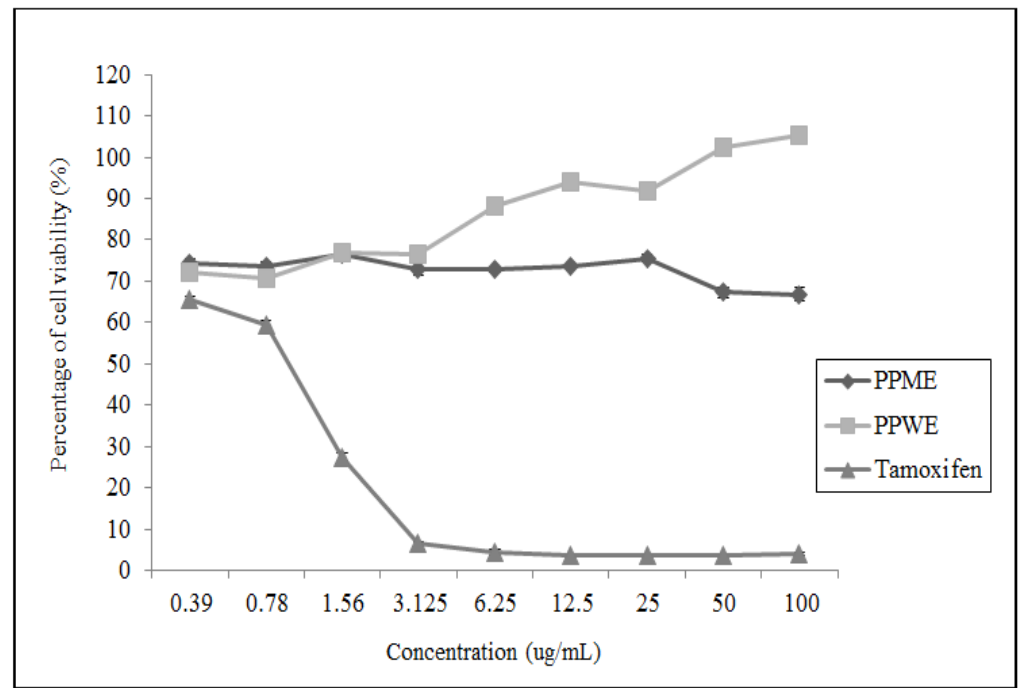

Figure 2. The Percentage of Cells Viability of L929 Cell at Different Concentrations of PPME, PPWE and Tamoxifen

quantitative results are recorded based on the retention time (rt), compound mass and percentage of peak area of detected compounds. From the analyses, 31 and 28 bioactive compounds were identified in P. piloselloides of methanol and water extracts. 2-Furancarboxaldehyde, 5-(hydroxymethyl) (23.13\%), allopurinol (8.66), 4H-Pyran-4-one, 2,3-dihydro-3,5-dihydroxy-6-methyl(7.41\%), n-hexadecanoic acid (5.98\%) and 1,3,5-Triazine$2,4,6$-triamine $(5.34 \%)$ were discovered to be the most discrimant phytochemical compounds in PPME.

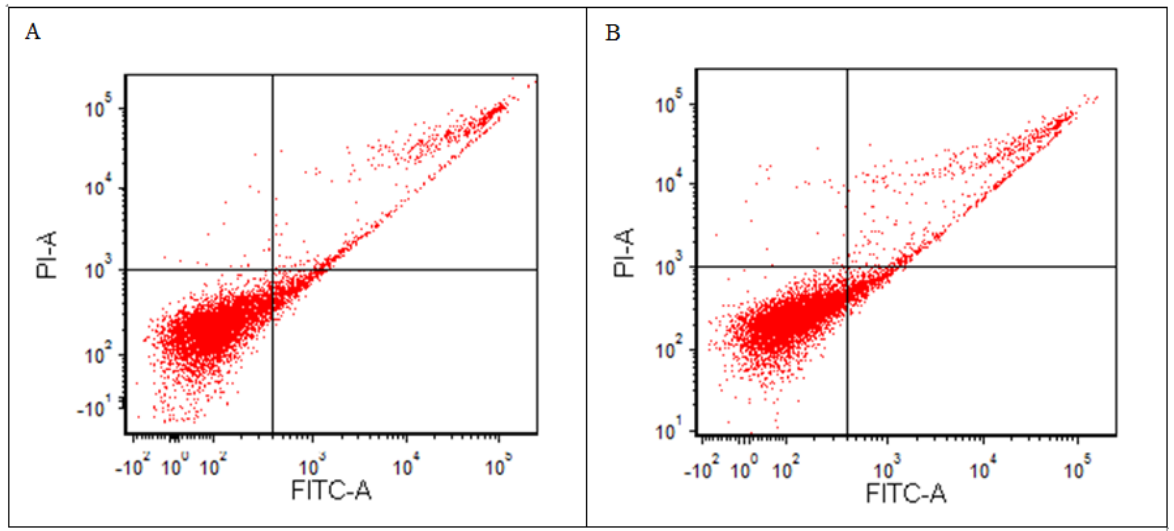

Figure 3. Scatter Plot Diagram of Apoptosis Rate Through Flow Cytometry Analysis of HeLa Cell after 72 Hours PPME Treatment at $\mathrm{IC}_{50}$ Value. Apparently, no decipherable changes have exhibited within the 24, 48 and 72 hours of observations. The figure is representing the PPME treatment on HeLa cell within periods. (A) Untreated HeLa cell; (B) Treated HeLa cell, (Q3) Live cell, (Q4) Early apoptosis, (Q2) Late apoptosis, (Q1) Necrotic/dead cell. 
Table 2. Bioactive Components Identified in PPME by GC-MS

\begin{tabular}{|c|c|c|c|c|}
\hline No & Rt & $\%$ Peak area & Name of compound & Molecular formula \\
\hline 1 & 3.27 & 1.24 & N,N-Dimethyltrimethylsilamine & $\mathrm{C} 5 \mathrm{H} 15 \mathrm{NSi}$ \\
\hline 2 & 4.26 & 3.67 & 2,4-Dihydroxy-2,5-dimethyl-3(2H)-furan-3-one & C6H8O4 \\
\hline 3 & 4.83 & 1.21 & 2H-Imidazole-2-thione, 1,3-dihydro -1-methyl- & $\mathrm{C} 3 \mathrm{H} 4 \mathrm{~N} 2 \mathrm{~S}$ \\
\hline 4 & 4.92 & 0.48 & 1,3,6-Trioxocane, 2-methyl & C6H12O3 \\
\hline 5 & 5.22 & 5.34 & 1,3,5-Triazine-2,4,6-triamine & C3H6N6 \\
\hline 6 & 5.28 & 1.08 & 2-Furancarboxylic acid, hydrazide & $\mathrm{C} 5 \mathrm{H} 6 \mathrm{~N} 2 \mathrm{O} 2$ \\
\hline 7 & 5.73 & 0.53 & 2-Propanamine, N-methyl-N-nitroso- & $\mathrm{C} 4 \mathrm{H} 10 \mathrm{~N} 2 \mathrm{O}$ \\
\hline 8 & 5.81 & 7.41 & 4H-Pyran-4-one, 2,3-dihydro-3,5-dihydroxy-6-methyl- & C6H8O4 \\
\hline 9 & 5.99 & 3.17 & Benzoic Acid & $\mathrm{C} 7 \mathrm{H} 6 \mathrm{O} 2$ \\
\hline 10 & 6.15 & 0.85 & 4H-Pyran-4-one, 3,5-dihydroxy-2-methyl- & C6H6O4 \\
\hline 11 & 6.33 & 1.94 & Butanedioic acid & $\mathrm{C} 4 \mathrm{H} 6 \mathrm{O} 4$ \\
\hline 12 & 6.38 & 2.57 & Benzofuran, 2,3-dihydro- & $\mathrm{C} 8 \mathrm{H} 8 \mathrm{O}$ \\
\hline 13 & 6.51 & 23.13 & 2-Furancarboxaldehyde, 5-(hydroxymethyl) & $\mathrm{C} 6 \mathrm{H} 6 \mathrm{O} 3$ \\
\hline 14 & 6.64 & 2.85 & 1,2,3-Propanetriol, diacetate & $\mathrm{C} 7 \mathrm{H} 12 \mathrm{O} 5$ \\
\hline 15 & 7.15 & 1.41 & 2-Methoxy-4-vinylphenol & $\mathrm{C} 9 \mathrm{H} 10 \mathrm{O} 2$ \\
\hline 16 & 7.19 & 1.03 & 2-Naphthalenol & $\mathrm{C} 10 \mathrm{H} 8 \mathrm{O}$ \\
\hline 17 & 7.72 & 1.62 & Benzene, 1-chloro-2-methoxy- & $\mathrm{C} 7 \mathrm{H} 7 \mathrm{ClO}$ \\
\hline 18 & 8.02 & 8.66 & Allopurinol & $\mathrm{C} 5 \mathrm{H} 4 \mathrm{~N} 4 \mathrm{O}$ \\
\hline 19 & 8.19 & 1.52 & 6-Hydroxymethaqualone & $\mathrm{C} 16 \mathrm{H} 14 \mathrm{~N} 2 \mathrm{O} 2$ \\
\hline 20 & 8.42 & 2.19 & 3,4-Altrosan & $\mathrm{C} 6 \mathrm{H} 10 \mathrm{O} 5$ \\
\hline 21 & 9.24 & 5.45 & Benzenepropanoic acid, 4-hydroxy- & $\mathrm{C} 9 \mathrm{H} 10 \mathrm{O} 3$ \\
\hline 22 & 10.28 & 0.37 & 1-Pentadecene & $\mathrm{C} 15 \mathrm{H} 30$ \\
\hline 23 & 10.9 & 5.98 & n-Hexadecanoic acid & $\mathrm{C} 16 \mathrm{H} 32 \mathrm{O} 2$ \\
\hline 24 & 11.66 & 2.31 & Phytol & $\mathrm{C} 20 \mathrm{H} 40 \mathrm{O}$ \\
\hline 25 & 11.75 & 1.85 & 9,12-Octadecadienoic acid (Z,Z)- & $\mathrm{C} 18 \mathrm{H} 32 \mathrm{O} 2$ \\
\hline 26 & 11.78 & 4.73 & 9,12,15-Octadecatrien-1-ol, (Z,Z,Z)- & $\mathrm{C} 18 \mathrm{H} 32 \mathrm{O}$ \\
\hline 27 & 12.52 & 0.38 & Benzene, 6-heptynyl- & $\mathrm{C} 13 \mathrm{H} 20$ \\
\hline 28 & 14.75 & 0.5 & $2,6,10,14,18,22-$ Tetracosahexaene & $\mathrm{C} 30 \mathrm{H} 50$ \\
\hline 29 & 17.91 & 1.28 & Ergost-8(14)-en-3-ol, (3.beta.)- & $\mathrm{C} 28 \mathrm{H} 48 \mathrm{O}$ \\
\hline 30 & 18.22 & 1.03 & Stigmasterol & $\mathrm{C} 29 \mathrm{H} 48 \mathrm{O}$ \\
\hline 31 & 18.85 & 4.23 & Stigmast-7-en-3-ol, (3.beta.,5.alpha.,24S)- & $\mathrm{C} 29 \mathrm{H} 50 \mathrm{O}$ \\
\hline
\end{tabular}

Rt, retention time; PPME, P. piloselloides methanol extract

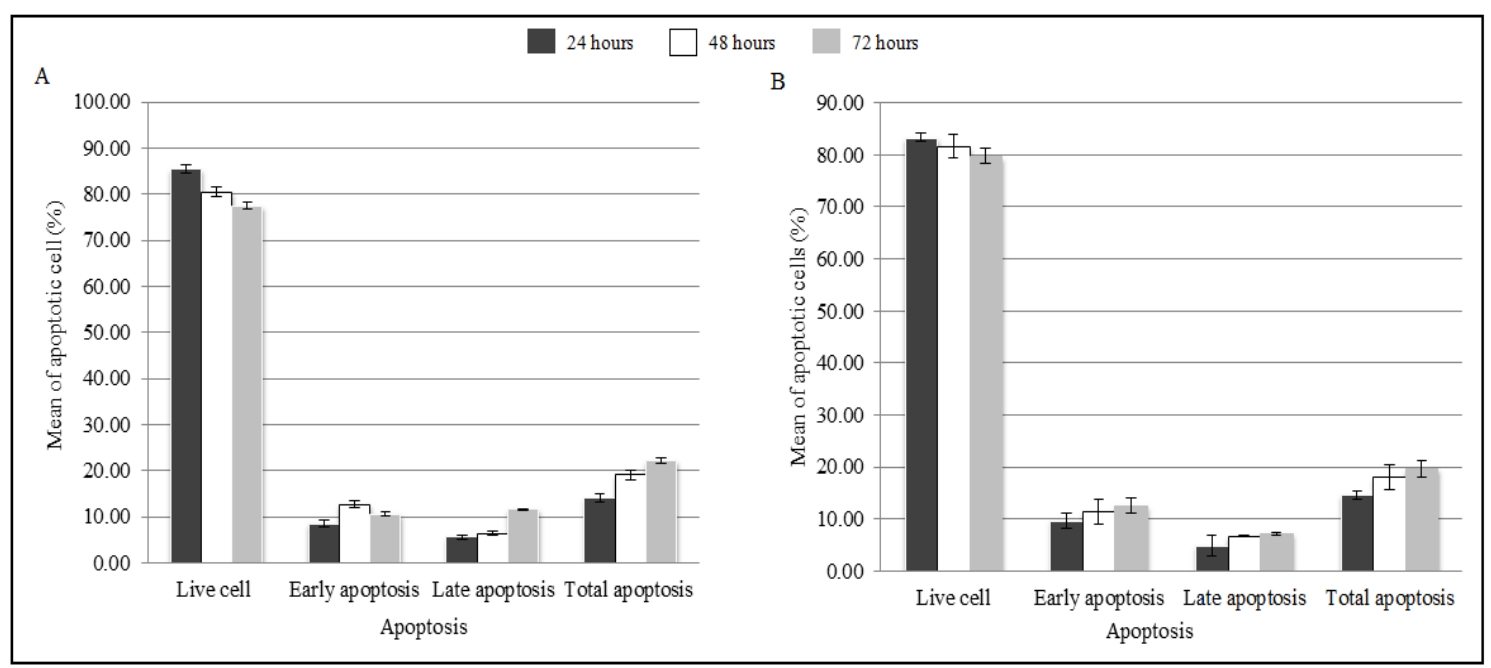

Figure 4. Graph Summary of Apoptosis Assessment the Cell Growth of HeLa Cell after 24, 48 and 72 hours. A, Untreated HeLa cell lines; B, Treated HeLa cells lines. 
Table 3. Bioactive Components Identified in PPWE by GC-MS

\begin{tabular}{|c|c|c|c|c|}
\hline No & Rt & $\%$ Peak area & Name of compound & Molecular Formula \\
\hline 1 & 3.93 & 3.63 & 2-Cyclopenten-1-one, 2-hydroxy & $\mathrm{C} 6 \mathrm{H} 8 \mathrm{O} 2$ \\
\hline 2 & 4.58 & 7.41 & Cyclobutaneoctol & $\mathrm{C} 4 \mathrm{H} 8 \mathrm{O} 8$ \\
\hline 3 & 5.14 & 4.22 & 2,5-Dimethyl-4-hydroxy-3(2H)-furanone (Furaneol) & $\mathrm{C} 6 \mathrm{H} 8 \mathrm{O} 3$ \\
\hline 4 & 5.47 & 10.06 & Thiophene-3-ol, tetrahydro-, 1,1-dioxide & $\mathrm{C} 4 \mathrm{H} 8 \mathrm{O} 3 \mathrm{~S}$ \\
\hline 5 & 6.37 & 6.43 & 2-Pentene, 2-methoxy & $\mathrm{C} 6 \mathrm{H} 12 \mathrm{O}$ \\
\hline 6 & 6.56 & 2.84 & Benzofuran, 2,3-dihydro & $\mathrm{C} 8 \mathrm{H} 8 \mathrm{O}$ \\
\hline 7 & 6.78 & 3.66 & Naphthalene, 2,6-bis(1,1-dimethylethyl)- & $\mathrm{C} 18 \mathrm{H} 24$ \\
\hline 8 & 7.2 & 5.77 & 2-Methoxy-4-vinylphenol & $\mathrm{C} 9 \mathrm{H} 10 \mathrm{O} 2$ \\
\hline 9 & 7.33 & 1.29 & 1,3-Bis(trimethylsiloxy)benzene & $\mathrm{C} 12 \mathrm{H} 22 \mathrm{O} 2 \mathrm{Si} 2$ \\
\hline 10 & 7.47 & 1.76 & 2-Ethyl-2,3-dihydro-1H-indene & $\mathrm{C} 11 \mathrm{H} 14$ \\
\hline 11 & 7.63 & 1.21 & Propenone, 3-(2-benzoxazolylthio)-1-phenyl- & $\mathrm{C} 16 \mathrm{H} 11 \mathrm{NO} 2 \mathrm{~S}$ \\
\hline 12 & 7.75 & 4.68 & Tributylamine & $\mathrm{C} 12 \mathrm{H} 27 \mathrm{~N}$ \\
\hline 13 & 7.94 & 1.55 & Phenol, 2-(1,1-dimethylethyl)-4-(1-methyl-1-phenylethyl)- & $\mathrm{C} 23 \mathrm{H} 32 \mathrm{O}$ \\
\hline 14 & 8.06 & 1.02 & Methylphosphonothiodifluoride & $\mathrm{CH} 3 \mathrm{~F}$ \\
\hline 15 & 8.1 & 4.37 & 1-Ethylcyclopropanol & $\mathrm{C} 5 \mathrm{H} 10 \mathrm{O}$ \\
\hline 16 & 8.21 & 1.22 & 7H-1-Benzopyran-7-one, 5-methoxy-6-methyl-2-phenyl & $\mathrm{C} 17 \mathrm{H} 14 \mathrm{O} 3$ \\
\hline 17 & 8.69 & 1.1 & 4-Hydroxyphenylacetic acid, ethylester, tert-butyldimethylsilyl & $\mathrm{C} 16 \mathrm{H} 26 \mathrm{O} 3 \mathrm{Si}$ \\
\hline 18 & 9.62 & 0.84 & 2-(p-(Dimethylamino)phenyl)benzimidazole & $\mathrm{C} 15 \mathrm{H} 15 \mathrm{~N} 3 \mathrm{O} 2$ \\
\hline 19 & 10.46 & 0.76 & Carbazole, pentamethyl- & $\mathrm{C} 12 \mathrm{H} 9 \mathrm{~N}$ \\
\hline 20 & 10.74 & 2.35 & Hexadecanoic acid, methyl ester & $\mathrm{C} 17 \mathrm{H} 34 \mathrm{O} 2$ \\
\hline 21 & 10.92 & 5.14 & Pentadecanoic acid & $\mathrm{C} 15 \mathrm{H} 30 \mathrm{O} 2$ \\
\hline 22 & 11.81 & 9.06 & Octadec-9-enoic acid & $\mathrm{C} 18 \mathrm{H} 34 \mathrm{O} 2$ \\
\hline 23 & 12.35 & 1.05 & Cyclononasiloxane, octadecamethyl- & C18H54O9Si9 \\
\hline 24 & 12.98 & 1.42 & Octadec-9-enoic acid & $\mathrm{C} 18 \mathrm{H} 34 \mathrm{O} 2$ \\
\hline 25 & 13.35 & 1.77 & Butane, 1-(benzyloxy)-2-[(benzyloxy)methyl]- & $\mathrm{C} 5 \mathrm{H} 12$ \\
\hline 26 & 18.3 & 4.33 & Stigmastan-3,5,22-trien & $\mathrm{C} 29 \mathrm{H} 46$ \\
\hline 27 & 18.8 & 4.33 & 7-Dehydrodiosgenin 3-acetate & $\mathrm{C} 29 \mathrm{H} 42 \mathrm{O} 4$ \\
\hline 28 & 19.1 & 7.98 & .beta.-Sitosterol acetate & $\mathrm{C} 31 \mathrm{H} 52 \mathrm{O} 2$ \\
\hline
\end{tabular}

Rt, retention time; PPWE, P piloselloides water extract

Whereas, the most major compounds existed in PPWE are thiophene-3-ol, tetrahydro-, 1,1-dioxide (10.06\%), octadec-9-enoic acid (9.06\%), beta-sitosterol acetate (7.98\%), cyclobutaneoctol $(7.41 \%)$ and 2-pentene, 2-methoxy $(6.43 \%)$. Moreover, there are two similar compounds encountered present in both extracts when using methanol as mobile phase which are benzofuran, 2,3-dihydro (rt at 6.38 in PPME and 6.56 in PPWE) and 2-Methoxy-4-vinylphenol (rt at 7.15 in PPME and 7.2 in PPWE).

\section{Discussion}

Botanicals are gaining massive attention in therapeutics management for cancer due to their efficacy to inhibit critical processes of cancer growth, angiogenesis and metastasis with minimal side effects and domestic reachable too. Nowadays, more researchers are exploring and innovating the compounds from natural sources such herbs and plants for cancer prevention or treatment used. Due to that, almost two over third of new drugs for malignant treatments today are originated from the compounds of natural sources (Wang et al., 2013).
Recently, various studies have demonstrated in vitro and/or in vivo that a number of plants able to suppress the infected cell and potentially become an anticancer agents (Mishra and Das, 2015; God et al., 2010; Gomathinayagam et al., 2008). In fact, some of the plants have been reported to be a promising antiproliferative to $\mathrm{CxCa}$ cell for instances Passiflora foetida (Talik Sisin, 2016), Lawsonia inermis (Kumar et al., 2015), Ophiocoma erinaceus (Baharara et al., 2016) and so forth (Kwon et al., 2006; Li et al., 2007; Kwon et al., 2007; Kim et al., 2010).

According to National Cancer Institute, substance with the $\mathrm{IC}_{50}$ value lower than or equal to $20 \mu \mathrm{g} / \mathrm{mL}$ has appropriate cytotoxic attribution and potential to be formulated as an anticancer agent. In the present study, PPME has exhibited the IC50 value on HeLa cell at $16.25 \mu \mathrm{g} / \mathrm{mL}$ while no cell growth inhibition occurred in mammalian normal cell line, L292. The attitude of PPME considerably ideal to be a cervical anticancer agent as the extract has only reacted to the dysplasia cells but not to the normal's. In contrast, even though no significant proliferative activity was established, PPWE has been noticed to induce positive effect on normal cell growth but constantly inactive in HeLa cell in dose-dependent 
manner (Table 1, Figures 2 and 3). Thus, it can be indicated that this epiphyte plant may contain the bioactive compounds which possess both antiproliferative effect and cell proliferative stimulator in cell-dependent manner. Moreover, from the MTT test result, it is proved that $P$. piloselloides leaves is a non-toxic part plant and can be safely consumed as a traditional/alternative medicine. However, further studies should be performed to solidify the aforementioned findings and isolate the potential compounds beforehand for new drugs development either for neoplasm defected cell inhibitor or as cell growth enhancer.

The methanol extract of $P$. piloselloides at IC50 value gained from the cell viability test, MTT, was further examined to flow cytometric analysis for analyzing the cell cycle and apoptosis of the HeLa cells using Annexin V/PI staining method. The apoptosis assessment of HeLa cell was studied at 24, 48 and 72 hours after the PPME treatments. While staining with Annexin V is typically useful for identification of early and late apoptosis cells. Viable cells with intact membrane are impermeable to PI stain, whereas the membranes of dead and damaged cells are permeable to it. Notably, there was no significant change in total apoptosis at particular hours after PPME treatment compared to the untreated HeLa cells as shown in Figures 3 and 4. This data states that PPME is able to inhibit the proliferation of $\mathrm{CxCa}$ cell in time- and dose-dependent manner, yet does not exhibit a significant effect on the mortality of cell in apoptosis cell cycle within the 72 days period. Same observations was also documented by Boulaaba et al., (2013), Chacko et al., (2012) and Wicaksono et al., (2009). In such case, previous researchers have come across that the apoptopic effect of PPME towards the cancer cell HeLa might have a little delayed and the effect will only can be seen if the observation period would be prolonged to more than 72 hours as reported in a study by (Konarikova et al., 2015). Another possible reason is, PPME might comprise with the element which work directly to cell cycle progress or direct hormonal link rather than through the apoptosis pathway in order to diminish cancer cell, HeLa as studied by Boulaaba et al., (2013) and Arditi et al., (2007). Nevertheless, more researches should be performed to affirm the hypothesis above.

Both extracts have been evaluated through GC-MS to specify the bioactive compounds present in the extracts. The GC-MS analysis of PPME revealed the presence of 2-Furancarboxaldehyde, 5-(hydroxymethyl) at the highest level, $23.13 \%$ and could be the main contributor to medicinal quality of $P$. piloselloides leaves. It was previously reported that, 2-Furancarboxaldehyde, 5-(hydroxymethyl) or also known as 5-HMF exhibits antioxidant and inhibitory effect on human melanoma A375 cell lines (Zhao et al., 2013). He has suggested that the compound could be developed as a novel natural antioxidant with potential applications in cancer chemoprevention. The highest compound identified in PPWE was thiophene-3-ol, tetrahydro-, 1,1-dioxide (also known as sulfolan-3-ol) with 10.06\%. Tilstam (2012) stated that sulfolan-3-ol is a dipolar aprotic industrial solvent, usually used in oil refining and gas production.
However, till to date, no study has been published to relate the compound with any antiproliferative or anticancer activity. Pertaining to the present MTT result, PPWE consists of sulfolan-3-ol contributes to negative cytotoxicity effect to the HeLa and L292 normal cells. Further investigations needs to be done to define the association and mechanism of anti-proliferative effect among highest compounds in PPME and PPWE such as 5-HMF, allopurinol, DDMP-4-1 with $\mathrm{CxCa}$ and nonmalignant cells.

To reiterate, $P$. piloselloides is a potent anticancer agent since it produced the IC50 value $<20 \mu \mathrm{g} / \mathrm{mL}$ on HeLa cell line though no significant apoptosis induction was promoted within 72 hours observation. This might also be a good indication that the cytotoxic compounds in that extracts might have less toxicity and exhibit cytoselectivity towards mammalian normal cells with the IC50 value was more than $100 \mu \mathrm{g} / \mathrm{mL}$. As a result, it is an encouraging evidence for the usage of $P$. piloselloides as cancer traditional/alternative medicine. To the best of our knowledge, this study is the first to conduct on the antiproliferative activity on cancer cell.

\section{Funding Statement}

This study was supported by the Fundamental Research Grant Scheme (FRGS) 203/PPSP/6171164 and the Research University Individual (RUI) 1001. PPSK.8012209 research grant.

\section{Statement conflict of Interest}

All authors declare having no conflict of interest and are fully responsible for all experimental works and the content of this article.

\section{Acknowledgements}

Authors would like to acknowledge Ministry of Higher Education (MOHE) for the financial support under the Fundamental Research Grant Scheme (FRGS) 203/PPSP/6171164 and Universiti Sains Malaysia for RUI 1001.PPSK.8012209 grant. Many appreciations and thanks go to Craniofacial Laboratory, School of Dental Sciences, Molecular Laboratory, Department of Hematology and Central Research Laboratory (CRL), School of Medical Sciences, USM for the facilities.

\section{References}

Alternative Medicine (2002). Anti-cancer compound found in Malaysia's Aphrodisiac Plant. World Scientific Publishing Co. Pte. Ltd., 6, p 595.

Arditi J, Venihaki M, Karalis K, Chrousos G (2007). Antiproliferative effect of adiponectin on MCF7 breast cancer cells: A potential hormonal link between obesity and cancer. Horm Metab Res, 39, 9-13.

Baharara J, Amini E, Namvar F (2016). Evaluation of the antiproliferative effects of Ophiocoma Erinaceus methanol extract against human cervical cancer cells. Avicenna J Med Biotechnol, 8, 29-35.

Boulaaba M, Mkadmini K, Tsolmon S, et al (2013). In vitro Antiproliferative effect of Arthrocnemum Indicum extracts on Caco-2 cancer cells through cell cycle control and related 
Phenol LC-TOF-MS identification. Evid Based Complement Alternat Med, 10, 1-12.

Bruni L, Barrionuevo-Rosas L, Albero G, et al (2016). Human papillomavirus and related diseases in the world. ICO Information Centre on HPV and Cancer (HPV Information Centre). 1-2987.

Chacko T, Menon A, Nair SV, Alsuhaibani E, Nair CK (2012). Cytotoxic and antitumor activity of the extract of Clerodendron infortunatum: A mechanistic study. Am J Phytomed Clin Therap, 3, 145-58.

God J, Tate PL, Larcom LL (2010). Red Raspberries have antioxidant effects that play a minor role in the killing of stomach and colon cancer cells. Nutr Res, 30, 777-82.

Gomathinayagam R, Sowmyalakshmi S, Mardhatillah F, et al (2008). Anticancer mechanism of Plumbagin, A natural compound, on non-small cell lung cancer cells. Anticancer Res, 28, 785-92.

Health Ministry of Malaysia. (2009). Management of cervical cancer (Second edition). Malaysian Health Technology Assessment Section (MaHTAS).

International Agency for Research on Cancer; GLOBOCAN 2012 v1.0. (2013). Cancer Incidence and Mortality Worldwide: IARC CancerBase No. 11.

Kim H, Moon JY, Mosaddik A, Cho SK (2010). Induction of apoptosis in human cervical carcinoma Hela cells by polymethoxylated flavone-rich citrus grandis Osbeck (Dangyuja) leaf extract. Food Cheml Toxicol, 48, 2435-42.

Konarikova K, Jezovicova M, Kereste J, et al (2015). Anticancer effect of black tea extract in human cancer cell lines. SpringerPlus, 4, 1-6.

Kumar M, Kaur P, Kumar S, Kaur S (2015). Antiproliferative and apoptosis inducing effects of non-polar fractions from Lawsonia inermis L. in cervical (Hela) cancer cells. Physiol Mol Biol Plants, 21, 249-60.

Kwon HJ, Bae SY, Kim KH, et al (2007). Induction of apoptosis in Hela cells by ethanolic extract of Corallina pilulifera. Food Chem, 104, 196-201.

Kwon HJ, Hong YK, Kim KH, et al (2006). Methanolic extract of pterocarpus santalinus induces apoptosis in hela cells. J Ethnopharmacol, 105, 229-34.

Li H, Wang L-J, Qiu G-F, et al (2007). Apoptosis of Hela cells induced by extract from cremanthodium humile. Food Chem Toxicol, 7, 2040-46.

Lin K (2005). Ethnobotanical study of medicinal plants used by the Jah Hut peoples in Malaysia. Indian J Med Sci, 59, 156-61.

Malaysian National Cancer Registry Report (2016). Malaysia cancer statistics, data and figure 2007-2011.

Mishra A, Das BC (2015). Curcumin as an anti-human papillomavirus and anti-cancer compound. Future Oncol, 11, 2487-90.

Neamsuvan O, Sengnon N, Haddee U, Mard-E W, Sae-Tang W (2014). Medinical plants in tropical rain forest from Hua Khao Subdistrict, Singha Nakhon District, Songkhla Province, Thailand. Am-Eurasian J Sustain Agric, 8, 1-11.

Sahid A, Pandiangan D, Siahaan P, Rumondor MJ (2013). Uji Sitotoksisitas Ekstrak Metanol Daun Sisik Naga (Drymoglossum piloselloides Presl.) Terhadap Sel Leukemia P388. Jurnal Mipa UNSRAT Online, 2, 94-9.

Talik Sisin NN (2016). Antiproliferative and antioxidant activities of Passifora Foetida methanol extracts and its fractions on selected cancer cells. 3rd Pan-Asian Biomedical Science Conference.

Tian Q, Zang YH (2015). Antiproliferative and apoptotic effects of the ethanolic herbal extract of Achillea falcata in human cervical cancer cells are mediated via cell cycle arrest and mitochondrial membrane potential loss. JBUON, 20,
1487-96.

Tilstam U (2012). Sulfolane: A versatile dipolar aprotic solvent. Org Process Res Dev, 16, 1273-8.

Torre LA, Bray F, Siegel RL, et al (2015). Global cancer statistics, 2012. CA Cancer J Clin, 65, 87-108.

Wan Ghazali WAS, Ab Alim A, Kannan TP, et al (2016). Anticancer properties of Malaysian herbs: A review. Arch Orofacial Sci, 11, 19-25.

Wang S-J, Zheng C-J, Peng C, et al (2013). Plants and cervical cancer: An overview. Expert Opin Investig Drugs, 22, 1133-56.

Wicaksono BD, Handoko YA, Arung ET, et al (2009). Antiproliferative effect of the methanol extract of Piper crocatum Ruiz and Pav leaves on human breast. Trop $J$ Pharm Res, 8, 345-52.

World Health Organisation (2014). Comprehensive Cervical Cancer Control.

Wulandari ET, Elya B, Hanani E, Pawitan JA (2013). In vitro antioxidant and cytotoxicity activity of extract and fraction Pyrrosia piloselloides (L) M. G Price. Int J PharmTech Res, 5, 119-25.

Zhao L, Chen J, Su J, et al (2013). In vitro antioxidant and antiproliferative activities of 5-hydroxymethylfurfural. $J$ Agric Food Chem, 61, 10604-11.

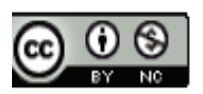

This work is licensed under a Creative Commons AttributionNon Commercial 4.0 International License. 